\title{
Effect of Exenatide, Metformin and Folic Acid on Experimentally Induced Metabolic-Cognitive Syndrome in Rats
}

\author{
Ahmed F. Bahriz, Mohamed Mansour, Amany N. Ibrahim, Doaa M. Khalil, Heba El-Noury
}

\begin{abstract}
Department of clinical pharmacology, Benha faculty of medicine, Banha University, Egypt
\end{abstract}

Correspondence to: Doaa M. Khalil, department of clinical pharmacology, Benha faculty of medicine, Banha University, Egypt

Email:

nadabassem14@yahoo.com

Received: 19 January 2020

Accepted: 18 March 2020

\begin{abstract}
:
Background: Metabolic syndrome (MetS) and its relationship with cognitive impairment has been the subject of extensive research. Purpose: This study was designed to determine the effect of MetS on cognitive function, and the possibility of modulating this effect by exenatide, metformin and folic acid. Materials and Methods: 30 adult male albino rats were divided in 5 groups. Group (I): received a standard rat chow, group (II): none treated rats with MetS fed with $60 \%$ fructose added to the standard rat chow, group (III): rats with MetS treated with exenatide, group (IV): rats with MetS treated with metformin, group (V): rats with MetS treated with folic acid. At the end of the experiment, fasting blood glucose, fasting plasma insulin, HOMA-IR index, serum triglyceride, HDL-C, dopamine and BDNF levels in brain tissue were measured and cognitive performance was assessed by Morris water maze (MWM) test. Results: rats with MetS showed increased levels of fasting blood glucose, fasting plasma insulin, HOMA-IR index, arterial blood pressure, serum triglycerides, decreased HDL-C, dopamine and BDNF and showed memory impairment in MWM test. All treated groups resulted in decrease in fasting blood glucose, fasting plasma insulin, HOMA-IR index, arterial blood pressure, and serum triglycerides and increase in HDL-C,
\end{abstract} dopamine and BDNF as well as improvement in MWM test. Conclusion: MetS was associated with cognitive impairment. Exenatide, metformin and folic acid improved cognitive function in addition to improvement of metabolic parameters.

Key words: cognition, exenatide, folic acid, metabolic syndrome, metformin.

Abbreviations: BDNF: Brain-derived neurotrophic factor, HDL-C: High density lipoprotein cholesterol, MetS: metabolic syndrome, MWM: Morris water maze. 


\section{INTRODUCTON:}

Metabolic syndrome (MetS) is a clustering of abdominal obesity, insulin resistance (IR), atherogenic dyslipidemia and elevated blood pressure (1) and is associated with other comorbidities including prothrombotic state, proinflammatory state, nonalcoholic fatty liver disease, and reproductive disorders $(2,3,4)$.

Several factors of MetS have been linked to cognitive impairment and dementia (5). Accordingly, it can be said that MetS, which is considered as risk factor for the development of diabetes, hypertension, dyslipidemia, and coronary artery disease can also act as an important risk factor for the development of dementia. This understanding has given rise to the concept of Metabolic Cognitive Syndrome (6).

Glucagon like peptide-1 (GLP-1) is an incretin hormone that regulates blood-glucose levels. It enhances glucose-dependent insulin secretion and lowers blood-glucose in subjects with type 2 diabetes (T2DM). The first incretin-mimetic, exenatide, is a potent and selective agonist for the GLP-1 receptor and has been widely used for the treatment of T2DM (7).

Glucagon like peptide-1 plays important roles in the brain, and acts as a neurotransmitter. 230
GLP-1 receptors expressed on neurons, have growth factor-like properties and protects neurons from neurotoxic influences. Since, exenatide may play an important role in blocking diabetes-induced memory deterioration; it may be a candidate for alleviation of cognitive disorders (8).

Metformin, an oral antihyperglycemic agent, is the most frequently used drug for treatment of T2DM. Inhibition of gluconeogenesis in the liver via activating the 5 ' adenosine monophosphate-activated protein kinase (AMPK) is the main molecular mechanism of metformin action (9).

Recently, several studies have examined the use of metformin in the treatment of neurodegenerative diseases such as Alzheimer's disease (AD), mild cognitive impairment and Parkinson's disease (10,11).

Folic acid is important in the nervous system at all ages and there is growing evidence of its involvement in the ageing brain, especially in mood and cognitive function. Recent epidemiological and clinical data suggest that persons with low folic acid levels are at increased risk of $\mathrm{AD}$ (12).

PURPOSE: Study the effect of MetS on cognitive function, modulating this effect by 
drug interventions and compare the beneficial effect of exenatide, metformin and folic acid on cognitive impairment associated with MetS.

\section{METHODS:}

This prospective study was done on 30 adult male albino rats weighing $150-200 \mathrm{~g}$ were used. Rats were acclimatized for one week and were caged (4/cage) in fully ventilated room with 12 hours light/dark cycles in Clinical Pharmacology Department, Benha Faculty of Medicine from September to November 2018. Approval from institutional ethical committee was obtained. Rats were divided into two parts:

Part 1: 6 rats received standard chow diet and tap water (group I).

Part 2: 24 rats fed with 60\% fructose added to standard chow diet for 8 weeks for induction of MetS $(13,14)$. At the end of $8^{\text {th }}$ week, rats were subdivided into 4 groups:

Group (II): MetS group continued on standard chow diet and tap water.

Group (III): MetS group continued on standard chow diet and tap water with exenatide $(10 \mu \mathrm{g} / \mathrm{kg} /$ day s.c. $)(15,16)$ for 4 weeks.

Group (IV): MetS group continued on standard chow diet and tap water with metformin $(250 \mathrm{mg} / \mathrm{kg} /$ day/orally $)(\mathbf{1 7}, \mathbf{1 8})$ for 4 weeks.

Group (V): MetS group continued on standard chow diet and tap water with folic acid $(10 \mathrm{mg} / \mathrm{kg} /$ day/orally $)(12,19)$ for 4 weeks.

At the end of the experiment (12 weeks) the following parameters were performed:

\section{(1) MWM test:}

A circular pool filled with $28^{\circ} \mathrm{C}$ opaque water to a depth of $40 \mathrm{~cm}$ was divided into 4 quadrants by 4 starting points marked on its wall: North, South, East and West. A circular platform $9 \mathrm{~cm}$ in diameter was placed in the pool $2 \mathrm{~cm}$ below water level mounted on a column. The platform provided the only escape from water and was fixed in the center of one of the 4 quadrants.

The experiment started by placing the rat in the pool from 4 different randomly chosen start positions with the head facing the wall. The rat swims around until it finds the hidden platform to stand on or for duration of one minute. The escape latency, the time to reach the platform, was recorded for each animal. If a rat could not find the platform within one minute, it was guided to the platform and allowed to stay there for 10 seconds; the latency was scored as one minute. Acquisition trials were performed 
four times daily for five consecutive days. The second day after the last trial, the platform was removed and animals were allowed to swim freely for one minute, the time spent in the target quadrant and the numbers of crossing the platform were recorded to test retention memory (19).

\section{(2) Blood pressure:}

Rats were placed in the restrainer, the pneumatic cuff fitted over the rats' tail, then inflated to occlude the pulse and allowed to deflate slowly until the pulse pressure observed on the pulse channel of the lab chart. A two-channel recorder was used to obtain a record of both pulse and cuff pressure (20).

(3) Biochemical studies: Rats were overnight fasted for 12 hours; rats were anesthetized and then were fixed on operating table and the blood samples were collected to measure:

a. Fasting blood glucose (FBG): Achieved by dimedone precipitation (21).

b. Fasting plasma insulin: Assayed by ratspecific enzyme immunoassay (22).

c. HOMA-IR index: IR measured using homeostasis model assessment ratio defined by the following formula $(23,24)$

d. FBG (mg/dl) $x$ Fasting plasma insulin $(\mu \mathrm{IU} / \mathrm{mL})$ HOMA-IR $=405$ e. Serum triglycerides: Enzymatic colorimetric test according to (GPO-PAP) method (25).

f. Serum HDL-C: Separation of high density lipoproteins and determination of cholesterol bound to these fractions (26).

(4) Dopamine and BDNF in brain tissue:

Sample preparation: Anesthetized animals were decapitated; brain was excised, trimmed of connective tissues, rinsed in icecold Phosphate Buffered Saline (PBS) to remove excess blood, one hemisphere weighed. Brain tissues were minced and homogenized in a certain amount of PBS with a glass homogenizer on ice. The resulting suspension was subjected to ultrasonication or to two freeze-thaw cycles to further break the cell membranes. The homogenates were centrifugated for 15 minutes at $1500 \times \mathrm{g}$. Remove the supernatant and assay immediately or aliquot and store samples at $-20^{\circ} \mathrm{C}$ or $-80^{\circ} \mathrm{C}(27,28)$.

Principle of assay: Dopamine ELISA kit applies competitive enzyme immunoassay technique utilizing monoclonal anti-dopamine antibody (29). BDNF ELISA kits applies sandwich enzyme immunoassay technique utilizing antibody specific for rat BDNF (30).

STATISTICAL ANALYSIS: Data tabulated and analyzed using SPSS version 16 software (Spss Inc, Chicago, ILL USA Company). Data were expressed as mean \pm standard 
deviation. Differences among variables were tested using one-way analysis of variance (ANOVA). Significant ANOVA test were followed by post-hoc multiple comparisons using Bonferroni tests to detect significant pairs (31) and $p<0.05$ was considered significant.

\section{Results:}

(1) MWM test (table 1,2):

- MetS group showed significant increase in escape latency on $3^{\text {rd }}, 4^{\text {th }}$ and $5^{\text {th }}$ days and significant decrease in the number of crossing the platform and the time spent in the target quadrant compared to control group.

- Exenatide group showed significant decrease in escape latency on $3^{\text {rd }}, 4^{\text {th }}$ and $5^{\text {th }}$ days while metformin and folic acid groups showed significant decrease in escape latency on $4^{\text {th }}$ and $5^{\text {th }}$ days compared to MetS group. All treated groups showed significant increase in the number of crossing the platform and the time spent in the target quadrant compared to MetS group.

\section{(2) Blood pressure (table 3):}

- MetS group showed significant increase in systolic and mean blood pressure compared to control group $(p<0.05)$. Exenatide and metformin groups showed significant decrease in systolic and mean blood pressure $(p<0.05)$, while folic acid group showed insignificant decrease of systolic and mean blood pressure compared to MetS group $(p>0.05)$. Exenatide group showed significant decrease in systolic blood pressure compared to metformin group $(p<0.05)$ and significant decrease in systolic and mean blood pressure compared to folic acid group $(p<0.05)$.

\section{(3) FBG, fasting plasma insulin and HOMA-} IR index (table 4):

- MetS group showed significant increase $(p<0.05)$ in FBG, fasting plasma insulin and HOMA-IR index compared to control group. All treated groups showed significant decrease $(p<0.05)$ in $\mathrm{FBG}$, fasting plasma insulin and HOMA-IR index compared to MetS group. Both exenatide and metformin groups showed significant decrease $(p<0.05)$ in FBG, fasting plasma insulin and HOMA-IR index compared to folic acid group.

(4) Serum triglycerides and HDL-c (table 5):

- MetS group showed significant increase $(p<0.05)$ in triglycerides and significant decrease in HDL-C compared to control group. All treated groups showed significant decrease $(p<0.05)$ in triglycerides and significant increase in HDL-C compared to MetS group. Exenatide group showed significant decrease $(p<0.05)$ in triglycerides and significant increase $(p<0.05)$ in HDL-C compared to folic acid group, while metformin group showed significant increase $(p<0.05)$ in HDL-C compared to folic acid group. 
(5) Dopamine and BDNF in brain tissue (table 6):

- MetS group showed significant decrease $(p<0.05)$ in dopamine and BDNF compared to control group. All treated groups showed significant increase $(p<0.05)$ in dopamine and
BDNF compared to MetS group. Exenatide showed significant increase $(p<0.05)$ in dopamine and BDNF compared to folic acid and significant increase $(p<0.05)$ in BDNF compared to metformin. Metformin showed significant increase in BDNF compared to folic acid $(p<0.05)$.

Table (1): Effect of treatment with exenatide (10 $\mu \mathrm{g} / \mathrm{kg} /$ day s.c for 4 weeks), metformin ( $250 \mathrm{mg} / \mathrm{kg} / \mathrm{day}$ p.o for 4 weeks) and folic acid (10mg/kg/day p.o for 4 weeks) on Morris water maze test.

\begin{tabular}{|c|c|c|c|c|c|}
\hline Escape latency in sec & $\begin{array}{l}\mathbf{1}^{\text {st }} \text { day (mean } \pm \\
\text { SD) }\end{array}$ & $\begin{array}{l}2^{\text {nd }} \text { day } \\
\text { (mean } \pm \\
\text { SD) }\end{array}$ & $\begin{array}{c}3^{\text {rd }} \text { day } \\
(\text { mean } \pm \\
\text { SD) }\end{array}$ & $\begin{array}{c}4^{\text {th }} \text { day } \\
(\text { mean } \pm \\
\text { SD) }\end{array}$ & $\begin{array}{l}5^{\text {th }} \text { day }(\text { mean } \pm \\
\text { SD) }\end{array}$ \\
\hline Control group & $28.3 \pm 3.6$ & $20.3 \pm 4.0$ & $14.0 \pm 5.2$ & $11.7 \pm 4.7$ & $8.7 \pm 2.9$ \\
\hline $\begin{array}{l}\text { Metabolic syndrome non treated } \\
\text { group }\end{array}$ & $36.0 \pm 15.5$ & $34.0 \pm 17.0$ & $32.0^{\mathrm{a}} \pm 15.0$ & $31.2^{\mathrm{a}} \pm 15.5$ & $29.2^{a} \pm 13.6$ \\
\hline Exenatide-treated group & $28.7 \pm 3.8$ & $23.7 \pm 6.0$ & $17.7^{\mathbf{b}} \pm 5.3$ & $16.3^{b} \pm 4.8$ & $12.3^{\mathbf{b}} \pm 3.2$ \\
\hline Metformin -treated group & $30.0 \pm 5.2$ & $26.7 \pm 4.5$ & $20.5 \pm 4.1$ & $18.3^{\mathbf{b}} \pm 3.8$ & $15.0^{\mathbf{b}} \pm 2.4$ \\
\hline Folic acid-treated group & $31.7 \pm 5.5$ & $29.0 \pm 5.2$ & $23.0 \pm 4.8$ & $19.5^{\mathbf{b}} \pm 1.4$ & $17.2^{\mathbf{b}} \pm 3.1$ \\
\hline \multicolumn{6}{|c|}{ Data are presented as mean $(\mathrm{M}) \pm \mathrm{SD}$} \\
\hline \multicolumn{6}{|c|}{ a: Significant difference versus control at $\mathrm{p}<0.05$. } \\
\hline \multicolumn{6}{|c|}{ b: Significant difference versus non treated group at $\mathrm{p}<0.05$. } \\
\hline \multicolumn{6}{|c|}{ c: Significant difference versus exenatide treated group at $\mathrm{p}<0.05$. } \\
\hline \multicolumn{6}{|c|}{ d: Significant difference versus metformin treated group at $\mathrm{p}<0.05$. } \\
\hline \multicolumn{6}{|c|}{$\begin{array}{l}\text { Table (2): Effect of treatment with exenatide }(10 \mu \mathrm{g} / \mathrm{kg} / \text { day s.c for } 4 \text { weeks }) \text {, metformin }(250 \mathrm{mg} / \mathrm{kg} / \mathrm{day} \text { p.o for } 4 \\
\text { weeks) and folic acid }(10 \mathrm{mg} / \mathrm{kg} / \text { day p.o for } 4 \text { weeks) on Morris water maze test }\end{array}$} \\
\hline & \multicolumn{3}{|c|}{$\begin{array}{l}\text { No. of crossing the platform } \\
(\text { mean }+ \text { SD) }\end{array}$} & $\begin{array}{l}\text { nt in the targ } \\
\text { (mean } \pm\end{array}$ & $\begin{array}{l}\text { SD) } \\
\text { SDuadrant in sec }\end{array}$ \\
\hline Control group & \multicolumn{3}{|c|}{$\frac{(\operatorname{mean} \pm \mathbf{S D})}{7 \pm 0.6}$} & \multicolumn{2}{|c|}{$33.7 \pm 1.6$} \\
\hline \multicolumn{2}{|c|}{$\begin{array}{l}\text { Metabolic syndrome non treated group } \\
\text { Exenatide-treated group }\end{array}$} & \multicolumn{2}{|c|}{$\begin{array}{l}\mathbf{a} \pm 0.6 \\
\mathbf{a}, \mathbf{b} \pm 0.9\end{array}$} & \multicolumn{2}{|c|}{$\begin{array}{c}11^{\mathbf{a}} \pm 1.5 \\
23.3^{\mathbf{a}, \mathbf{b}} \pm 1.2\end{array}$} \\
\hline $\begin{array}{l}\text { Metformin -treated group } \\
\text { Folic acid-treated group }\end{array}$ & \multicolumn{3}{|c|}{$\begin{array}{c}5^{\mathbf{a , b}} \pm 0.7 \\
4.5^{\mathbf{a}, \mathbf{b}} \pm 0.5\end{array}$} & \multicolumn{2}{|c|}{$\begin{array}{l}23^{\mathbf{a , b}} \pm 1.4 \\
22^{\mathbf{a , b}} \pm 1.3\end{array}$} \\
\hline
\end{tabular}

Data are presented as mean $(\mathrm{M}) \pm \mathrm{SD}$
a: Significant difference versus control at $\mathrm{p}<0.05$.
b: Significant difference versus non treated group at $\mathrm{p}<0.05$.
c:Significant difference versus exenatide treated group at $\mathrm{p}<0.05$.
d: Significant difference versus metformin treated group at $\mathrm{p}<0.05$. 
Table (3):Effect of treatment with exenatide $(10 \mu \mathrm{g} / \mathrm{kg} / \mathrm{day}$ s.c for 4 weeks), metformin $(250 \mathrm{mg} / \mathrm{kg} / \mathrm{day} \mathrm{p} . \mathrm{o}$ for 4 weeks) and folic acid (10mg/kg/day p.o for 4 weeks) on systolic and mean arterial blood pressure in metaboliccognitive syndrome.

\begin{tabular}{lll}
\hline & $\begin{array}{l}\text { Systolic BP }(\mathbf{m m} . \mathbf{H g}) \\
(\text { mean } \pm \text { SD) }\end{array}$ & $\begin{array}{l}\text { Mean arterial BP }(\mathbf{m m} . \mathbf{H g}) \\
(\text { mean } \pm \text { SD) }\end{array}$ \\
\hline Control group & $109.3 \pm 4.1$ & $85.8 \pm 3.1$ \\
Metabolic syndrome non treated group & $162.8^{\mathrm{a}} \pm 4.4$ & $132.2^{\mathrm{a}} \pm 2.3$ \\
Exenatide-treated group & $148^{\mathrm{a}, \mathrm{b}} \pm 3.0$ & $115^{\mathrm{a}, \mathrm{b}} \pm 3.4$ \\
Metformin -treated group & $155.5^{\mathrm{a}, \mathrm{b}, \mathrm{c}} \pm 4.8$ & $119.7^{\mathrm{a}, \mathrm{b}} \pm 3.5$ \\
Folic acid-treated group & $157.5^{\mathrm{a}, \mathrm{c}} \pm 2.9$ & $125.2^{\mathrm{a}, \mathrm{c}} \pm 2.8^{-9}$ \\
\hline
\end{tabular}

Data are presented as mean $(\mathrm{M}) \pm \mathrm{SD}$

a: Significant difference versus control at $\mathrm{p}<0.05$.

b: Significant difference versus non treated group at $\mathrm{p}<0.05$.

c: Significant difference versus exenatide treated group at $\mathrm{p}<0.05$.

$\mathrm{d}$ : Significant difference versus metformin treated group at $\mathrm{p}<0.05$.

Table (4): Effect of treatment with exenatide $(10 \mu \mathrm{g} / \mathrm{kg} /$ day s.c for 4 weeks), metformin $(250 \mathrm{mg} / \mathrm{kg} / \mathrm{day} \mathrm{p} . \mathrm{o}$ for 4 weeks) and folic acid (10mg/kg/day p.o for 4 weeks) on fasting blood glucose, fasting plasma insulin and HOMA-IR index in metabolic- cognitive syndrome.

\begin{tabular}{|c|c|c|c|}
\hline & $\begin{array}{l}\text { Fasting blood glucose } \\
\text { mg/dl } \\
(\text { mean } \pm \text { SD) }\end{array}$ & $\begin{array}{l}\text { Fasting } \\
\text { insulin level } \\
\mu \mathrm{IU} / \mathrm{ml} \\
(\text { mean } \pm \text { SD) }\end{array}$ & $\begin{array}{l}\text { HOMA IR index } \\
(\text { mean } \pm \text { SD })\end{array}$ \\
\hline Control group & $77 \pm 5.9$ & $1.1 \pm 0.28$ & $0.21 \pm 0.07$ \\
\hline Metabolic syndrome non treated group & $298.3^{a} \pm 6.8$ & $9.1^{\mathrm{a}} \pm 0.27$ & $6.71^{\mathrm{a}} \pm 0.28$ \\
\hline Exenatide-treated group & $118.2^{\mathrm{a}, \mathrm{b}} \pm 4.2$ & $3.15^{\mathrm{a}, \mathrm{b}} \pm 0.19$ & $0.92^{\mathrm{a}, \mathrm{b}} \pm 0.08$ \\
\hline Metformin -treated group & $125.8^{\mathrm{a}, \mathrm{b}} \pm 5.6$ & $4.2^{\mathrm{a}, \mathrm{b}, \mathrm{c}} \pm 0.24$ & $1.31^{\mathrm{a}, \mathrm{b}, \mathrm{c}} \pm 0.13$ \\
\hline Folic acid-treated group & $189.8^{\mathrm{a}, \mathrm{b}, \mathrm{c}, \mathrm{d}} \pm 4.3$ & $6.0^{\mathrm{a}, \mathrm{b}, \mathrm{c}, \mathrm{d}} \pm 0.23$ & $2.81^{\mathrm{a}, \mathrm{b}, \mathrm{c}, \mathrm{d}} \pm 0.14$ \\
\hline
\end{tabular}

Data are presented as mean $(\mathrm{M}) \pm \mathrm{SD}$

a: Significant difference versus control at $\mathrm{p}<0.05$.

b: Significant difference versus non treated group at $\mathrm{p}<0.05$.

c: Significant difference versus exenatide treated group at $\mathrm{p}<0.05$.

$\mathrm{d}$ : Significant difference versus metformin treated group at $\mathrm{p}<0.05$ 
Table (5):Effect of treatment with exenatide $(10 \mu \mathrm{g} / \mathrm{kg} / \mathrm{day}$ s.c for 4 weeks), metformin $(250 \mathrm{mg} / \mathrm{kg} / \mathrm{day} \mathrm{p} . \mathrm{o}$ for 4 weeks) and folic acid (10mg/kg/day p.o for 4 weeks) on serum triglycerides and HDL- cholesterol in metaboliccognitive syndrome.

\begin{tabular}{lll}
\hline & $\begin{array}{l}\text { Serum triglycerides }(\mathrm{mg} / \mathrm{dl}) \\
(\text { mean } \pm \text { SD) }\end{array}$ & $\begin{array}{l}\text { Serum HDL- C (mg/dl) } \\
(\text { mean } \pm \text { SD) }\end{array}$ \\
\hline Control group & $92 \pm 6.0$ & $43.3 \pm 1.5$ \\
Metabolic syndrome non treated group & $158.0^{\mathrm{a}} \pm 6.3$ & $28.8^{\mathrm{a}} \pm 1.8$ \\
Exenatide-treated group & $129.0^{\mathrm{a}, \mathrm{b}} \pm 3.5$ & $39.0^{\mathrm{a}, \mathrm{b}} \pm 0.9$ \\
Metformin -treated group & $135.0^{\mathrm{a,b}} \pm 6.4$ & $37.5^{\mathrm{a}, \mathrm{b}} \pm 1.9$ \\
& & $34.0^{\mathrm{a,b}, \mathrm{c,d}} \pm 0.9$ \\
\hline
\end{tabular}

Data are presented as mean $(\mathrm{M}) \pm \mathrm{SD}$

a: Significant difference versus control at $\mathrm{p}<0.05$.

b: Significant difference versus non treated group at $\mathrm{p}<0.05$.

c: Significant difference versus exenatide treated group at $\mathrm{p}<0.05$.

$\mathrm{d}$ : Significant difference versus metformin treated group at $\mathrm{p}<0.05$.

Table (6): Effect of treatment with exenatide (10 $\mu \mathrm{g} / \mathrm{kg} /$ day s.c for 4 weeks), metformin $(250 \mathrm{mg} / \mathrm{kg} / \mathrm{day} \mathrm{p} . \mathrm{o}$ for 4 weeks) and folic acid (10mg/kg/day p.o for 4 weeks) on dopamine and BDNF levels in brain tissue in metaboliccognitive syndrome.

\begin{tabular}{lll}
\hline & $\begin{array}{l}\text { Dopamine in brain tissue }(\mathrm{ng} / \mathrm{g} \\
\text { tissue }) \\
(\text { mean } \pm \mathrm{SD})\end{array}$ & $\begin{array}{l}\text { BDNF in brain tissue }(\text { Pg/g } \\
\text { tissue) } \\
(\text { mean } \pm \mathrm{SD})\end{array}$ \\
\hline Control group & $610 \pm 13$ & $50.9 \pm 1.4$ \\
Metabolic syndrome non treated group & $390^{\mathrm{a}} \pm 12.6$ & $12.8^{\mathrm{a}} \pm 1.0$ \\
Exenatide-treated group & $480^{\mathrm{a}, \mathrm{b}} \pm 15.8$ & $30.1^{\mathrm{a}, \mathrm{b}} \pm 1.9$ \\
Metformin -treated group & $465^{\mathrm{a}, \mathrm{b}} \pm 8.9$ & $24.7^{\mathrm{a}, \mathrm{b}, \mathrm{c}} \pm 1.8$ \\
Folic acid-treated group & $455^{\mathrm{a}, \mathrm{b}, \mathrm{c}} \pm 10$ & $20.8^{\mathrm{a}, \mathrm{b}, \mathrm{c}, \mathrm{d}} \pm 1.8$ \\
\hline
\end{tabular}

Data are presented as mean $(\mathrm{M}) \pm \mathrm{SD}$

a: Significant difference versus control at $\mathrm{p}<0.05$.

b: Significant difference versus non treated group at $\mathrm{p}<0.05$.

c: Significant difference versus exenatide treated group at $\mathrm{p}<0.05$.

$\mathrm{d}$ : Significant difference versus metformin treated group at $\mathrm{p}<0.05$.

\section{DISCUSSION:}

The burden of MetS is becoming even more alarming on the light of recent reports suggesting that MetS disrupts brain function and resilience to neurological disorders (32). MetS increases the incidence of cognitive disorders in aging and $\mathrm{AD}$, and even in young individuals $(33,34)$.

Metabolic syndrome group showed hyperglycemia, hyperinsulinemia, IR, hypertension and dyslipidemia. These results are in agreement with other studies done on 
$2013 \&$ 2017) $(35,36)$. High flux of fructose to the liver disturbs normal hepatic carbohydrate metabolism and enhances de novo lipogenesis which lead to IR in humans and animals (37). Fructose elevated blood pressure through increased sympathetic nervous system activity, enhanced reninangiotensin system activity, increased sodium reabsorption and impaired endotheliumdependent relaxation (38).

Metabolic syndrome group decreased dopamine and BDNF and impaired performance in MWM test indicating cognitive impairment, this agreed with other studies $(39,40)$. Chronic fructose feeding (416 weeks) induce apoptosis and reduce hippocampal neurogenesis (41). Also, shorter periods induce autophagy in rat cerebral cortex and reduce the hippocampal weight (42).

Dopamine controls locomotor activity, cognition, emotions and feeding behavior (43). MetS group showed reduction in dopamine, these results agreed with others who stated that the brain dopamine level and the activity of DA2 receptors are weakened in MetS and T2DM. $(44,45)$

Brain-derived neurotrophic factor is the most widely distributed neurotrophin in the central nervous system. It plays a major role in regulating axonal and dendritic growth, longterm potentiation and neurotransmitter release 237
(46). MetS group showed reduction of BDNF as shown by others $(47,48)$. In humans, reduced BDNF expression is evident in preclinical phases of $\mathrm{AD}$ (49). Also changes in serum BDNF is associated with age related memory decline in late adulthood (50). Moreover, a novel polymorphism in BDNF gene was associated with late onset AD (51).

Morris water maze test is one of the primary methods used to evaluate cognitive impairment in rats (52). MetS group showed impaired performance in MWM test. Likewise, it was reported that high fructose impaired spatial memory in rats.(53)

Fasting blood glucose, insulin, and HOMA-IR were decreased with improvement of dyslipidemia and hypertension in MetS rats treated with exenatide, these results are in line with other studies done on 206 and 2017 (54, 55). Exenatide exert its beneficial effect on pancreas by maintaining optimal $\beta$-cell mass and function by increasing the $\beta$-cell gene expression, this may lead to $\beta$-cell proliferation and neogenesis

Additionally, GLP-1 impairs $\beta$-oxidation and de novo lipogenesis in the hepatocyte and modulates reverse cholesterol transport (57).

The antihypertensive effect of exenatide was demonstrated in rat model of MetS (58). Other studies reported that exenatide reduced blood pressure in subjects with elevated blood pressures. (59). Furthermore, another study 
(60) reported that exenatide has a novel antihypertensive effect as GLP-1 is a vasodilator, induces c-GMP and c-AMP release. Another target of GLP-1 in the brain is the dopaminergic system (61). In the present study, exenatide increased dopamine level. Exenatide upregulates the expression of tyrosine hydroxylase catalyzing the conversion of tyrosine into L-DOPA (62). Also, exenatide increased BDNF, these results are in agreement with others, who demonstrated that mRNA level of BDNF was increased in the hippocampus of the diabetic mice treated with exenatide. (8)

Exenatide improved performance in MWM test. This was also reported previously as intracerebroventricular infusion of exenatide ameliorated cognitive functions in rats with hepatosteatosis. (63)

Furthermore, exenatide has cognitive enhancing effect even in presence of genetic neuronal dysfunction. This effect due to metabolic switch toward anaerobic glycolysis and increased production of lactate, two phenomena that can fuel the neurons in which a valid cognitive reserve is still present (7).

Metformin decreased FBG, insulin, HOMAIR index and triglycerides with elevation of HDL-C, these results were demonstrated in 2015 by other researchers (64). Metformin inhibits gluconeogenesis in the liver by activating the liver kinase B1 (LKB1)/AMPK 238 pathway through inhibiting the mitochondrial respiratory-chain complex-1 (65). Metformin improves IR by increasing insulin receptor expression and improving tyrosine kinase activity (66).

Metformin improved the lipid profile when administered alone or in combination with atorvastatin (67). It decreases mRNA expression of sterol regulatory elementbinding protein-1which upregulates enzymes involved in de novo fatty acid synthesis, such as acetyl-CoA carboxylase $(68,69)$.

Metformin decreased blood pressure; these results are in line with previous studies $(70,71,72)$, who concluded that metformin corrected the imbalance between endothelium-derived factors by reducing oxidative stress and suppressing the synthesis or release of vasoconstrictor prostanoids. Conflicting results was reported by Emeka \& Al-Ahmed (73), who found that doxorubicin induced hypotension, was restored by metformin.

In the present work, metformin increased dopamine and BDNF and improved performance in MWM test indicating cognitive improvement, these findings are in accordance with other researchers. (74).

Furthermore, treatment of 1-methyl-4-phenyl1, 2, 3, 6-tetrahydropyridine plus probenecidinduced mouse model of Parkinson's disease 
with metformin significantly increased dopamine level (75).

Regarding BDNF, our results were in accordance with others who found that rats treated with metformin after cerebral ischemia showed elevation of BDNF level (76). Also, in 2019 it was reported that diabetic patients taking metformin had higher serum BDNF levels due to increasing AMPK and tyrosine kinase activity (77)

Metformin improved performance in MWM test, these findings are in line with others who reported that learning and memory impairment induced by scopolamine was reversed by metformin $(78,79)$

Folic acid reduced FBG, insulin, HOMA-IR index and triglycerides with elevation of HDL-C. These results were proved before stating that folic acid supplementation improved glycemic control, decreased triglycerides and increased HDL-C levels (8081). Folic acid showed insignificant changes in blood pressure these findings are in agreement with McRae (82) and inconsistent with others, (83) who showed that folic acid improved endothelial dysfunction and decreased blood pressure.

Folic acid increased dopamine and BDNF and improved performance in MWM test indicating cognitive improvement; this in line with Yang and co-workers (19) who stated that folic acid attenuates diabetesinduced cognitive impairment.

Folic acid plays a role in the methylation of homocysteine providing methyl group for conversion of methionine to Sadenosylmethionine, which has an important role in the synthesis of tetrahydrobiopterin, an essential co-factor for the hydroxylation of phenylalanine and tryptophan, rate limiting steps in the synthesis of dopamine $(\mathbf{8 4}, 85)$.

Folic acid prevents the reduction in BDNF induced by homocysteine injection (86). Folic acid promotes hippocampal neurogenesis and preserves cognitive functions after stroke in the adult brain $(87,88)$. Additionally, alteration of maternal folic acid reduces BDNF levels in preterm pregnancy (89).

Conclusion: MetS was associated with cognitive impairment. Exenatide, metformin and folic acid improved cognitive function in addition to improvement of metabolic parameters.

\section{REFERENCES:}

1- Singh, N.S. (2018): Metabolic Syndrome: Practice Essentials, Background, Pathophysiology. J Heart Stroke. 3(1): 1044

2- Grundy, S.M. (2016): Metabolic syndrome update. Trends in Cardiovascular Medicine. Volume 26, Issue 4, Pages 364-373. 
3- Sarafidis, P.A. and Nilsson, L. (2006): The metabolic syndrome: a glance at its history. J.Hypertens 24:621626.

4- McCracken, E.; Monaghan, M. and Sreenivasan, S. (2018): Pathophysiology of the metabolic syndrome. Clinics in Dermatology, 36(1): 14-20.

5- Mellendijk, L.; Wiesmann, M.; Kiliaan, A.J. (2015): Impact of nutrition on cerebral circulation and cognition in the metabolic syndrome. Nutrients; 7:9416-39.

6- Grover, S. (2018): Metabolic-cognitive syndrome: Is this understanding useful? J.Geriatr.Ment. Health; 5:1-3.

7- Bomba, M.; Ciavardelli, D.E.; Silvestri, E.; Canzoniero, L.M.T.; Lattanzio, R.; Chiappini, P.; et al. (2013): Exenatide promotes cognitive enhancement and positive brain metabolic changes in PS1-KI mice but has no effects in 3xTg-AD animals. Cell Death and Disease .4, e612; .2013.139.

8- Gumuslua, E.; Mutlub, O.; Celikyurtb, I.K.; Ulakb, G.; Akarb,F.; Erdenb, F.; et al. (2016): Exenatide enhances cognitive performance and upregulates neurotrophic factor gene expression levels in diabetic mice. Fundamental \& Clinical Pharmacology. 30; 376384.

9- An, H. and He, L. (2016): Current understanding of metformin effect on the control of hyperglycemia in diabetes. J Endocrinol 228: 97-106.

10- Mahmood, K.; Naeem, M. and Rahimnajjad, N.A. (2013): Metformin: the hidden chronicles of a magic drug. European Journal of Internal Medicine, vol. 24, pp. 20-26.

11-Markowicz-Piasecka, M.; Sikora, J.; Mateusiak, L.; Mikiciuk-Olasik, E. and Huttunen, K.M. (2017): Metformin and Its Sulfenamide Prodrugs Inhibit Human
Cholinesterase Activity. Oxidative Medicine and Cellular Longevity. Volume 2017, 11 pages.

12- Shooshtari, M.K.; Moazedi, A.A. and Parham, G.A. (2012): Memory and Motor Coordination Improvement by Folic Acid Supplementation in Healthy Adult Male Rats. Iran J Basic Med Sci, 15 (6): 1173-1179.

13- Chou, C.L.; Lai, Y.H.; Lin, T.Y.; Lee, T.J. and Fang, T.C. (2011): Aliskiren prevents and ameliorates metabolic syndrome in fructose-fed rats. Arch Med Sci. 7(5): $882-888$.

14- Thomas, S.; Senthilkumar, G.P.; Sivaraman, K.; Bobby, Z.; Paneerselvam, S.; Harichandrakumar, K.T. (2015): Effect of S-Methyl-L-Cysteine on Oxidative Stress, Inflammation and Insulin Resistance in Male Wistar Rats Fed with High Fructose Diet. Iran J Med Sci. Vol. 40 No. 1.

15- Sedman, T.; Rünkorg, K.; Krass, M.; Luuk, H.; Plaas, M.; Vasar,E.; et al. (2016): Exenatide Is an Effective Antihyperglycaemic Agent in a Mouse Model of Wolfram Syndrome 1. Journal of Diabetes Research. Volume 2016. 7 pages.

16- Tanaka, K.; Masaki, Y.; Tanaka, M.; Miyazaki, M.; Enjoji, M.; Nakamuta, M.; et al. (2014): Exenatide improves hepatic steatosis by enhancing lipid use in adipose tissue in non diabetic rats. World $\mathbf{J}$ Gastroenterol; 20(10): 2653-2663.

17-Han, X.; Tao, Y.; Deng, Y.; Yu, J.; Cai, J.; Ren, G.;et al. (2017): Metformin ameliorates insulitis in STZ-induced diabetic mice. PeerJ. 5:e3155.

18- Okoh, M.P.; Nwose, C.; Nwachukwu, K.C. (2015): Comparative effects of Portulaca Oleracea and Metformin in Diabetes Mellitus Rat induced with Alloxan. J Pharm Chem Biol Sci. 3(3):358-366. 
19- Yang, R.; Chen, R.; Chen, H.; Zhang, H.; Cai,

D. (2014): Original Article Folic acid attenuates cognitive dysfunction in streptozotocin-induced diabetic rats. Int J Clin Exp Med; 7(11):4214-4219.

20- Ullian, M.E.; Islam, M.M.; Robinson, C.J.; Fitzgibbon, W.R.; Tobin, E.T. and Paul, R.V. (1997): Resistance to mineralocorticoids in wisterFurth rats. Am. J. Physiol.; 272: 111454-111461.

21- Efendic, S.; Karlander, S. and Vranic, $M$. (1988): Mild type II diabetes markedly increases glucose cycling in the post absorptive state and during glucose infusion irrespective of obesity. J Clin Invest; 81: 1953-1961.

22- Gerard, D.A.; David, M.P. and David, W.S. (2005): Fructose Feeding Increases Insulin Resistance but not Blood Pressure in SpragueDawley Rats. Hypertension; 46 : 806.

23- Matthews, D.R.; Hosker, J.P.; Rudenski, A.S.;Naylor, B.A.; Treacher, D.f. and Turner, R.C. (1985): Homeostasis model assessment -insulin resistance and beta-cell function from fasting plasma glucose and insulin concentration in man. Diabetaologia; 28:412-419.

24- Gargari, B.P.; Aghamohammadi, V.; Aliasgharzadeh, A. (2011): Effect of folic acid supplementation on biochemical indices in overweight and obese men with type 2 diabetes. Diabetes research and clinical practice. 94: 33 - 38.

25- Fossati, P. (1982): Enzmatic colorimeteric determination of serum triglycerides. Clin Chem; 28 : 2077.

26- Lopes-Virella, M.F.; Stone, P.; Ellis, S. and Colwell, J.A. (1977): Cholesterol determination in high-density lipoproteins separated by three different methods. Clin . chem., 23:(5):882-4.
27- Ciarlone, E.A. (1978): Determination of catecholamine sspectrophoto-flurometrically. Am J Physiol. 125:731-737.

28- Lowry, O.H.; Rosebrough, N.J.; Farr, A.L. and Randall, R.J. (1951): Protein measurement with the folin phenol reagent. J. Biol Chem.193:265-75.

29- Guo, Y.; Lee, H.; Lo, Y.; Yua, S. and Huang, S. (2018): n-3 polyunsaturated fatty acids prevent Dgalactose-induced cognitive deficits in prediabetic rats. Food Funct. 9, 2228-2239.

30- Dekel, T.; Assaf, L.; Roman, G.; Sharon, H. and Alon, C. (2011): Resilience to chronic stress is mediated by hippocampal brain-derived neurotrophic factor. J Neurosci. 31(12):4475-83.

31- Khothari, C.R. (2004): Research Methodology: Methods and Techniques, New Age International, New Delhi, 2004.

32- Trevino, S.; Aguilar-Alonso, P.; Flores Hernandez, J.A.; Brambila, E.; Guevara, J.; Flores, G.; et al. (2015): A high calorie diet causes memory loss, metabolic syndrome and oxidative stress into hippocampus and temporal cortex of rats. Synapse; $69: 421-433$.

33- Rios, J.A.; Cisternas, P.; Arrese, M.; Barja, S.; Inestrosa, N.C. (2014): Is Alzheimer's disease related to metabolic syndrome? A Wnt signaling conundrum. Prog Neurobiol. 121:125-146.

34- Chan, J.S.; Yan, J.H.; Payne, V.G. (2013): The impact of obesity and exercise on cognitive aging. Front Aging Neurosci. 5:97. 
35-Dupas, J.; Feray, A.; Goanvec, C.; Guernec, A.; Samson, N.; Bougaran, P.; et al. (2017): Metabolic Syndrome and Hypertension Resulting from Fructose Enriched Diet in Wistar Rats. Volume 2017 (5) 10 pages.

36- Huang, H.Y.; Korivi, M.; Tsai, C.H.; Yang, J.H.; Tsai, Y.C. (2013): Supplementation of Lactobacillus plantarum K68 and Fruit-Vegetable Ferment along with High Fat-Fructose Diet Attenuates Metabolic Syndrome in Rats with Insulin Resistance. Evid Based Complement Alternat Med. 2013:943020.

37- Basciano, H.; Federico, L. and Adeli, K. (2005): Fructose, insulin resistance, and metabolic dyslipidemia. Nutrition \& Metabolism, 2(1):5.

38- Abdulla, M.H.; Sattar, M.A. and Johns, E.J. (2011): The Relation between Fructose-Induced Metabolic Syndrome and Altered Renal Haemodynamic and Excretory Function in the Rat. Int J Nephrol. 2011: 934659.

39- Deme, S.M.; Nanu, P.D.; Jianu, C.D.; KoryCalomfirescu, S.; Ioncu, D.S. (2010): The correlation between cognitive decline and the incidence and the influence of metabolic syndrome in elderly subjects with mild cognitive decline. Journal Medical Aradean. 13: 11-18.

40- Ng, T.P.; Feng, L.; Nyunt, M.S.; Feng, L.; Gao, Q.; Lim, M.L.; et al. (2016): Metabolic syndrome and the risk of mild cognitive impairment and progression to dementia. JAMA Neurol. 73(4): 456-463.

41- Van der Borght, K.; Köhnke, R.; Göransson, N.; Deierborg, T.; Brundin, P.; Erlanson-Albertsson, C.;et al. (2011): Reduced neurogenesis in the rat hippocampus following high fructose consumption. Regul. Pept. 167, 26-30.
42- Spagnuolo, M.S.; Bergamo, P.; Crescenzo, R.; Iannotta, L.; Treppiccione, L.; Iossa, S.; et al. (2018): Brain Nrf2 pathway, autophagy, and synaptic function proteins are modulated by a short-term fructose feeding in young and adult rats. Nutr. Neurosci. 24, 1-12.

43- Undieh, A.S. (2010): Pharmacology of signaling induced by dopamine D1- like receptor activation. Pharmacol. Ther. 128, 37-60.

44- Pijl, H. and Edo, A.M. (2002): Modulation of monoaminergic neural circuits: potential for the treatment of Type 2 diabetes mellitus. Treat. Endocrinol. $1,71-78$.

45- Grunberger, G. (2013): Novel therapies for the management of Type 2 diabetes mellitus: part 1 . pramlintide and bromocriptine QR. J. Diabetes 5, 110117.

46- Tapia-Arancibia, L.; Aliaga, E.; Silhol, M. and Arancibia, S. (2008): New insights into brain BDNF function in normal aging and Alzheimer disease. Brain Research Reviews, 59 (1), 201-220.

47- Sangüesa, G.; Cascales, M.; Griñán, C.; Sánchez, R.M.; Roglans, N.; Pallàs, M.; et al . (2018): Impairment of novel object recognition memory and brain insulin signaling in fructose but not glucosedrinking female rats. Molecular Neurobiology. 55:69846999.

48- Stranahan, A.M.; Norman, E.D.; Lee, K.; Cutler, R.G.; Telljohann, R.S.; Egan, J.M.; et al. (2008): Dietinduced insulin resistance impairs hippocampal synaptic plasticity and cognition in middleaged rats. Hippocampus. 18(11):1085-1088.

49- Francis, B.M.; Kim, J.; Barakat, M.E.; Fraenkl, S.; Yücel, Y.H.; Peng, S.; et al. (2012): Object recognition memory and BDNF expression are 
reduced in young TgCRND8 mice. Neurobiol Aging. 33(3):555-563.

50-Kirk, L.; Ruchika, S.; Michelle, W.; Laura, C.; Suise, H.; Molly, M.; et al. (2010): Brain derived neurotrophic factor is associated with age-related decline in hippocampal volume. $\mathrm{J}$ Neurosci. 30(15):5368-75.

51-Kunugi, H.; Ueki, A.; Otsuka, M.; Isse, K.; Kato, N.; Nabika, T. (2001): A novel polymorphism of the Brain derived neurotrophic factor (BDNF) gene associated with late-onset Alzheimer's disease. Mol Psychiatry. 6(1):83-6.

52-Budni, R.; Pacheco, S.; Da Silva, M.L.; Garcez, F.; Mina, T.; Bellettini-Santos, J.; et al. (2016): Oral Administration of D-Galactose Induces Cognitive Impairments and Oxidative Damage in Rats, Behav. Brain Res., 302, 35-43.

53- Ross, A.P.; Bartness, T.J.; Mielke, J.G. and Parent, M.B. (2009): A high fructose diet impairs spatial memory in male rats," Neurobiology of Learning and Memory, vol. 92, no. 3, pp. 410-416.

54- Boshra,V. and Elkashef, W. (2017): Renal Insulin Sensitizing Effect of Exenatide in a High-fat Diet Obesity Rat Model. British Journal of Medicine \& Medical Research 20(6): 1-13.

55- Mack, C.M.; Moore, C.X.; Jodka, C.M.; Bhavsar, S.; Wilson, J.K.; Hoyt, J.A.; et al. (2006): Antiobesity action of peripheral exenatide (exendin-4) in rodents: Effects on food intake, body weight, metabolic status and side-effect measures. Inter J Obesity. 30:1332-1340.

56- Xu, Y.; Wei, Z.; Zhang, Z.; Xing, Q.; Hu, P.; Zhang, X.; et al. (2009): No association of the insulin gene VNTR polymorphism with polycystic ovary syndrome in a Han Chinese population. Reproductive Biology and Endocrinology. 7: 1-5.

57- Vishal, J.P.; Amit, A.J.; Gaurang, B.S.; Mukul, R.J. (2014): Effect of GLP-1 based therapies on diabetic dyslipidemia. Current Diabetes Reviews.10 (4):238-250.

58- Laugero, K.D.; Stonehouse, A.H.; Guss, S.; Landry, J.; Vu, C.; Parkes, D.G. (2009): Exenatide improves hypertension in a rat model of the metabolic syndrome. Metab Syndr Relat Disord. 7(4):327- 334

59- Blonde, L.; Klein, E.J.; Han, J.; Zhang, B.; Mac, S.M.; Poon, T.H.; et al. (2006): Interim analysis of the effects of exenatide treatment on A1C, weight and cardiovascular risk factors over 82 weeks in 314 overweight patients with type 2 diabetes. Diabetes Obes Metab. 8:436-447.

60- Dandona, P.; Chaudhuri, A. and Dhindsa, S. (2010): A Novel Antihypertensive Effect of Exenatide, a GLP-1 Agonist. American journal of hypertension. Volume 23 number 3. 228.

61-Shpakov, A.O.; Derkach, K.V. and Berstein, L.M. (2015): Brain signaling systems in the Type 2 diabetes and metabolic syndrome: promising target to treat and prevent these diseases. Future Sci. OA. 1(3), FSO25

62- Li, Y.; Perry, T.; Kindy, M.S.; Harvey, B.K.; Tweedie, D.; Holloway, H.W.; et al. (2009): GLP-1 receptor stimulation preserves primary cortical and dopaminergic neurons in cellular and rodent models of stroke and Parkinsonism. Proc. Natl Acad. Sci. USA. 106:1285-1290. 
63- Erbas, O.; Sarac, F.; Aktug, H. and Peker, G. (2014): Detection of Impaired Cognitive Function in Rat with Hepatosteatosis Model and Improving Effect of GLP-1 Analogs (Exenatide) on Cognitive Function in Hepatosteatosis. Scientific World Journal. Volume 2014. 5 pages.

64- Kuate, D.; Kengne, A.P.N.; Biapa, C.P.N.; Azantsa, B.G.K. and Muda, W.A.M. (2015): Tetrapleura tetraptera spice attenuates high-carbohydrate, high-fat diet-induced obese and type 2 diabetic rats with metabolic syndrome features. Lipids in Health and Disease. 2015: 14:50.

65- Rena, G.; Pearson, E.R.; Sakamoto, K. (2013): Molecular mechanism of action of metformin: old or new insights? Diabetologia, 56: 1898-906.

66-Viollet, B.; Guigas, B.; Sanz-Garcia, N.; Leclerc, J.; Foretz, M.; Andreelli, F. (2012): Cellular and molecular mechanisms of metformin: an overview. Clin Sci, 122: 253-70.

67- Paseban, M.; Mohebbati, R.; Niazmand, S.; Sathyapalan, T. and Sahebkar, A. (2019): Comparison of the Neuroprotective Effects of Aspirin, Atorvastatin, Captopril and Metformin in Diabetes Mellitus. Biomolecules. 9(4), 118.

68- Gutierrez-Repiso, C.; Rodriguez-Pacheco, F.; Garcia-Arnes, J.; Valdes, S.; Gonzalo, M.; Soriguer, F.; et al. (2015): The expression of genes involved in jejunal lipogenesis and lipoprotein synthesis is altered in morbidly obese subjects with insulin resistance. Lab. Investig. 95, 1409-1417.

69- Zhou, J.; Massey, S.; Story, D.; Li, L. (2018): Metformin: An Old Drug with New Applications. International Journal of Molecular Science. 19(10), 2863: 2878 .
70-Matsumoto, T.; Noguchi, E.; Ishida, K.; Kobayashi, T.; Yamada, N.; Kamata, K. (2008): Metformin normalizes endothelial function by suppressing vasoconstrictor prostanoids in mesenteric arteries from OLETF rats, a model of type 2 diabetes. Am J Physiol Heart Circ Physiol. 295: 1165-1176.

71- Huang, X.; Fan, R.; Lu, Y.; Yu, C.; Xu, X.; Zhang, X.; et al. (2014): Regulatory effect of AMP activated protein kinase on pulmonary hypertension induced by chronic hypoxia in rats: in vivo and in vitro studies. Mol Biol Rep. 41(6):4031-41.

72- Tomczyk, R.; Ociepka, A.; Kialka, M.; Milewicz, T.; Migacz, K.; Kowalczuk, A.; et al. (2015): Metformin and changes in blood pressure and heart rate in lean patients with polycystic ovary syndrome (PCOS)- preliminary study. Przegl Lek. 72(6):302-5.

73- Emeka, P.M. and Al-Ahmed, A. (2017): Effect of metformin on ECG, HR and BP of rats administered with cardiotoxic agent doxorubicin. Int $\mathrm{J}$ Basic Clin Pharmacol. 6:1054-9.

74- Pintana, H.; Apaijai, N.; Pratchayasakul, W.; Chattipakorn, N.; Chattipakorn, S.C. (2012): Effects of metformin on learning and memory behaviors and brain mitochondrial functions in high fat diet induced insulin resistant rats. Life Sci. 91(11-12): 409-414.

75- Lu, M.; Su, C.; Qiao, C.; Bian, Y.; Ding, J. and Hu, G. (2016): Metformin Prevents Dopaminergic Neuron Death in MPTP/P-Induced Mouse Model of Parkinson's Disease via Autophagy and Mitochondrial ROS Clearance. International Journal of Neuropsychopharmacology. 19(9):pyw047.

76- Ghadernezhad, N.; Khalaj, L.; Pazoki-Toroudi, H.; Mirmasoumi, M.; Ashabi, G. (2016): Metformin pretreatment enhanced learning and memory in cerebral forebrain ischemia: the role of the 
AMPK/BDNF/P70SK signaling pathway. Pharm Biol. 54(10):2211-2219.

77- Eyileten, C.; Mirowska-Guzel, D.; Milanowski, L.; Zaremba, M.; Rosiak, M.; Cudna, A.; et al. (2019): Serum Brain-Derived Neurotrophic Factor is related to Platelet Reactivity and Metformin Treatment in Adult Patients with Type 2 Diabetes Mellitus. Can J Diabetes. 43:19-26.

78-Aksoz, E.; Gocmez, S.S.; Sahin, T.D.; Aksit, D.; Aksit, H.; Utkan, T. (2019): The protective effect of metformin in scopolamine-induced learning and memory impairment in rats. Pharmacological Reports. Volume 71, Issue 5, Pages 818-825.

79- Mostafa, D.K.; Ismail, C.A. and Ghareeb, D.A. (2016): Differential metformin dose-dependent effects on cognition in rats: role of Akt. Psychopharmacology. 233:2513-2524.

80- Talari, H.R.; Rafiee, M.; Farrokhian, A.; Raygan, F.; Bahmani, F.; Darooghegi Mofrad, M.; et al. (2016): The Effects of Folate Supplementation on Carotid Intima-Media Thickness and Metabolic Status in Patients with Metabolic Syndrome. Ann. Nutr. Metab. 69(1):41-50.

81- Bahmani, F.; Galougahi, F.R.; Vahedpoor, Z.; Jamilian, M.; Mahmoodi, S.; Baghban, R.; et al. (2018): The Effects of Folic Acid Supplementation on Recurrence and Metabolic Status in Endometrial Hyperplasia: A Randomized, Double-Blind, PlaceboControlled Trial. Arch Iran Med. 21(10):452-459.

82- McRae, M.P. (2009): High-dose folic acid supplementation effects on endothelial function and blood pressure in hypertensive patients: a metaanalysis of randomized controlled clinical trials. Journal of Chiropractic Medicine. 8(1): 15-24.
83- Pravenec, M.; Kožich, V.; Krijt, J.; Sokolová, J.; Zídek, V.; Landa, V.; et al. (2013): Folate Deficiency Is Associated With Oxidative Stress, Increased Blood Pressure, and Insulin Resistance in Spontaneously Hypertensive Rats. American Journal of Hypertension. 26 (1). 135-140.

84- Mattson, M.P. and Shea, T.B. (2003): Folate and homocysteine metabolism in neural plasticity and neurodegenerative disorders. Trends in Neurosciences. 26, 137e146.

85- Taylor, M.J.; Carney, S.M.; Goodwin, G.M. and Geddes, J.R. (2004): "Folate for depressive disorders: systematic review and meta-analysis of randomized controlled trials". J. Psychopharmacol. (Oxford). 18 (2): 251-6.

86- Matte, C.; Pereira, L.O.; Dos-Santos, T.M.; Mackedanz, V.; Cunha, A.A.; Netto, C.A. et al. (2009): Acute homocysteine administration impairs memory consolidation on inhibitory avoidance task and decreases hippocampal brain-derived neurotrophic factor immunocontent: prevention by folic acid treatment. Neuroscience 163(4):1039-1045.

87- Iskandar, B.J.; Nelson, A.; Resnick, D.; Skene, J.H.; Gao, P.; Johnson, C.; et al. (2004): Folic acid supplementation enhances repair of the adult central nervous system. Ann Neurol. 56(2):221-227.

88- Zhang, X.; Huang, G.; Liu, H.; Chang, H. and Wilson, J.X. (2012): Folic acid enhances Notch signaling, hippocampal neurogenesis, and cognitive function in a rat model of cerebral ischemia. Nutr Neurosci. 15(2):55-61.

89- Dhobale, M. and Joshi, S. (2012): Altered maternal micronutrients (folic acid, vitamin B (12) and omega 3 fatty acids through oxidative stress may reduce neurotrophic factors in preterm 
pregnancy. J Maternal Fetal Neonatal Med.

25(4):317-323.

To cite this article: Ahmed F. Bahriz, Mohamed Mansour, Amany N. Ibrahim, Doaa M. Khalil, Heba El-Noury. Effect of exenatide, metformin and folic acid on experimentally induced metabolic-cognitive syndrome in rats. BMFJ. 2020; 37(1):229-245. DOI: 10.21608/bmfj.2020.22710.1206 